\title{
浅析乡村振兴视阈下留守老人获得感的实现路径
}

\author{
刘晰 王灿平 \\ 沈阳建筑大学 \\ DOI:10.32629/er.v3i7.2951
}

\begin{abstract}
[摘要] 近些年来我国经济的快速发展,经济结构和农村发展模式发生了迅速变化,农村地区的传统生 产和生活方式也发生了重大变化。特别是农村劳动力的不断外流,让我国传统的农村养老模式正在逐步 发生变化,形成了具有特色的农村老年人空巢的问题。农村留守老人是农民的重要组成部分,农村的空巢 家庭带来了很多实际的困难和问题。因此,如何提升农村留守老人的获得感是一个亟待解决的难题。

[关键词] 乡村振兴; 留守老人; 实现路径
\end{abstract}

在深入实施乡村振兴战略的过程中, 农村地区面临以下实际的问题: 农村家 庭的劳动力趋于老龄化, 导致农村地区 缺乏劳动力; 特别是中西部地区农村留 守老人的区域分化的扩大和劳动力向非 农业部门的跨地域迁移导致农村留守老 人的比例呈阶梯状分布, 从东向西逐渐 增加; 通常, 农村留守老人受教育程度低, 不拥有新的农业技术和设备, 远远不能 适应现代农业发展的需要; 农村留守老 人的教育和技术上的投资还相对较少, 这也会导致对现代农业发展的制约和留 守老人获得感的提升。

\section{1 农村留守老人问题的现状}

1.1劳动和经济负担较重

留在农村地区的绝大多数老年人 的经济来源取决于自己的工作收入和 子女的小额补贴, 大多数留守老年人的 收入主要取决于农作物的种植, 因为他 们的子女不在身边, 老年人必须自己进 行劳动, 或者雇人做, 并且普通农作物 种植所获取的利益是比较少的。而且随 着年龄的增长, 留守老人会逐渐丧失劳 动能力, 他们只能依靠孩子们的补贴。 尽管外出打工的年轻人收入相对来说 较高, 但他们通常为留守老年人提供有 限的经济支持, 而且这些形式的补贴还 往往取决于孩子对家长的孝顺程度和 收入水平, 并且不稳定, 没有规律性。目 前, 在大多数情况下, 老年人的抚养问 题是在老年人和孩子们之间进行协商
的基础上解决的, 具体取决于家庭的经 济状况, 但总的来说, 这些抚养费不是 很高, 只能支持日常生活。因此, 老年人 还需要做些艰苦的劳动来维持基本的 生活, 尤其是那些不想给自己的孩子增 加经济负担的老年人, 需要从事繁重的 农业劳动, 。同时, 大多数在外地工作的 孩子也将承包的土地转让给或者留给 父母进行耕种, 因此无疑会进一步增加 农村留守老人的负担。

\section{2 身体健康状况较差}

随着年龄的增长, 老年人健康状况 也会随着下降, 患病率增加, 再加上日常 医疗保障和医疗检查的不足, 许多留守 老年人不但有小病, 也不可避免地患有 严重的疾病。据统计, 农村地区老年人空 巢的疾病发生率要比城市高得多, 健康 状况差的人占 $65.15 \%$, 慢性病患者的占 $70-80 \%$, 尽管在农村留守老人参加了新 的统一的农村合作医疗, 但是一方面, 他 们抱怨医院费用太高, 每次生病时都吃 便宜的药品, 而大多不愿意选择到医院 就医; 另一方面, 出于经济原因, 许多人 不想花钱去看医生, 能够忍一下就得过 且过。目前我国农村留守老人生病以后, 由于孩子们不在身边, 难以得到及时有 效的照顾和就医, 而且也没有足够的经 济资源邀请保姆照顾。同时, 由于留守老 人中的许多人不能依靠相对稳定的经济 支持来减少患病的风险并及时彻底治疗, 这会导致获得感的不足, 并产生孤独和
无助的感觉。这些实际情况需要引起深 思, 并采取有效措施加以解决。

\section{3 心理健康状况不佳}

孤独的心理感觉是农村留守老人的 普遍问题。在农村地区, 越来越多的年轻 人外出工作和成对外出谋生, 这加剧了 农村家庭空巢的问题以及留守老年人养 老问题的困难。特别是年轻人带着孩子 一起外出务工生活后, 剩下的留守老人 不仅生活照顾不够全面, 甚至缺少一定 限度的精神安慰。虽然也有一些老人和 隔辈人一起生活, 他们的心理孤独感会 有一定的削弱, 但是在与隔辈人的交流 中, 存在着与另一代人的鸿沟, 由于这种 差距, 老年人也会产生一定的精神压力。 没有孩子关照的老人, 长时间孤独, 与外 界的接触更少, 最容易产生孤独感。另外, 农村的精神和文化生活还不够丰富, 缺 少适合的留守老人活动和放松的地方, “蹲在墙上, 寻找一些凉快的地方乘凉, 说话、看电视” 已成为许多老年人的轨 迹。大多数留守老年人都过着相对孤独 的生活: “出去一把锁, 进门一盏灯”, 长期下去会产生诸如孤独、沮丧、悲观、 痴呆或心理疾病等。此外, 随着留守老年 人的身体状况的下降, 其中一些人失去 了记忆, 他们无法活动甚至患上疾病 (残 疾), 也会常常受到日常生活行为而导致 隐匿的安全威胁, 特别针对老年人的人 身伤害、欺诈和其他犯罪等。因此, 他们 迫切需要与人开展广泛的沟通交流, 这 
不单单在很大程度上能够让老人感情舒 适, 同时还能够让老人心里得到慰藉。

\section{2 农村留守老人获得感实现路} 径研究

2. 1 强化與论宣传, 提高思想认识

解决农村老年人空巢的难题是一个 复杂而艰巨的社会系统工程, 它需要广 泛的参与, 出色的工作。因此, 需要加强 與论宣传, 提高全社会对于留守老人的 重视和关心、关爱, 加强关于老年人的法 律制定和老年人福利政策的完善工作, 在全社会和广大农民中宣传有关的法律 和法规, 大张旗鼓地宣传尊老敬老的先 进事迹, 表彰维护老年人合法权益的先 进典型, 唤醒人们对于留守老人这个特 殊群体予以特别的关注和足够的重视, 同时采取有力的措施予以援助, 切实帮 助他们解决一些实际困难, 在全社会形 成敬老爱老助老的浓厚氛围, 充分体现 社会主义制度的优越性。

\section{2 深入调查研究, 解决重点困难}

农村留守老年人的面临的困难很多, 但是不同的人困难程度也大不相同。有 些迫在眉睫需要解决精神上的安慰, 有 些需要解决经济费用上的问题, 而另一 些则需要解决自身对生活的乐观面对 等。基层工作者要深入实际, 认真区分不 同的情况, 解决不同留守老人群体所面 临的关键困难。各级干部是群众的主要 骨干, 应更多地履行照顾留守老人的责 任, 应当责任到户到人, 保持密切联系, 随时掌握情况, 及时解决各种困难, 尤其 是疾病医疗等问题。同时对于那些生活
半自理和不能自理的单身老人应想办法 集中供养和照护。

\section{3完善政策法规, 保护合法权益}

农村的留守老年还会反映出更多的 维权问题。无论是社会歧视问题, 涉及老 年人的有关违法行为, 还是互相推挤并 拒绝抚养老年人等问题, 均可通过法律 的手段捍卫老年人本身的合法权益。有 关部门应制定法律政策保护老年人的合 法权益, 如《中华人民共和国保护老年人 权益法》等法律规定, 做好保护留守老年 合法权益的工作, 如留守老人养老金的 提供, 医疗的完善、安全的保障和其他方 面的权益等, 建立和完善法律援助制度 等, 帮助老年人使用法律武器保护其合 法权益。

2. 4统筹城乡建设, 繁荣农村经济

农村地区的大量年轻人外出务工, 虽然可以使得农村家庭的经济水平获得 一定的提高, 但也因孩子寄养在家中, 使 得大部分钱都花在老年人与隔辈人在一 起生活的学费和生活费用上, 老年人的 经济收入可能并没有得到明显改善。这 些问题不仅应引起外出务工人员的注意, 而且应在更大程度上引起社会的关注。 因此, 需要制定切实可行的优惠政策, 积 极鼓励和指导外出务工的农民工返乡创 业, 农民工重返乡村创业, 不仅促进了农 村的经济的正常发展, 加快农村产业结 构战略性调整的步伐, 为农村经济和社 会的全面健康发展做出贡献, 而且会在 更大程度上使农村留守老年人能够真正 过上幸福的生活。今天, 老年人就是子孙
后代的明天, 每个人都需要他人的关爱, 全社会都应伸出援助之手, 奉献爱心, 共 同关爱照顾留守老人, 践行中华民族的 传统美德, 不断提升留守老人的获得感。

\section{3 结束语}

总之, 只有不断加强对留守老人的 关注, 为他们的幸福生活创造更多與论 环境、法治环境、道德环境, 创造更多的 条件, 让他们能够感受到社会和家庭的 关爱, 这也是统筹城乡发展中重要的一 环, 只有这样能才能够不断提升留守老 人的获得感。

\section{[参考文献]}

[1]凌紫嫣,李天舒, 张丹.以生态建 设与文化保留为特色的乡村留守老人活 动空间改造探讨—以湖南中山村为例 [J].现代园艺,2020,43(05):113-114.

[2]李茂松.乡村振兴视角下农村留 守老人生活现状及社会工作介入研究[J]. 产业与科技论坛,2019,18(23):82-84.

[3]常改红.农村养老设施室外交往 空间设计研究——以河南省三县(市)为 例[D].郑州:中原工学院,2017.

[4]间艳平,吴斌,张宇清,等.乡村景 观研究现状及发展趋势 [J]. 防护林科 技,2008,(3):105-108.

[5]赵一凡.老龄化社会老年人 居住环境设计探 讨 [J]. 现代园 艺,2017,(6):137-138。

[6]冉嘉诚.基于行为特征的养老院 室内交往空间设计研究一一重庆市养 老院为例[D].重庆:重庆大学,2017. 